\title{
EARLY SIGNS OF TRACHOMA OBSERVED BY THE SLIT LAMP*
}

\author{
BY \\ YAEJI ITO AND CHIANG-HUA YU \\ Department of Ophthalmology, Chiba University, Japan \\ Director: Professor Yaeji Ito
}

AFTER careful observation through Comberg's slit lamp (improved by Dr. Naito of Japan), the writers have clinically discovered the first sign of trachoma on the bulbar conjunctiva in 400 trachomatous eyes at different stages (according to MacCallan, 1936), twenty eyes with normal conjunctiva, and 58 eyes with epizoötic conjunctivitis. This finding has not previously been reported, and these observations should therefore be valuable to those who are called upon to diagnose the earliest stage of trachoma, from which the normal conjunctiva and every variety of epizoötic conjunctivitis are distinctly differentiated.

The corneal microscope of the slit lamp is directed to the part of the bulbar conjunctiva under observation, the illumination being given to the neighbouring area. The specific reflection from the surface of the conjunctiva is easily caught by the indirect illumination.

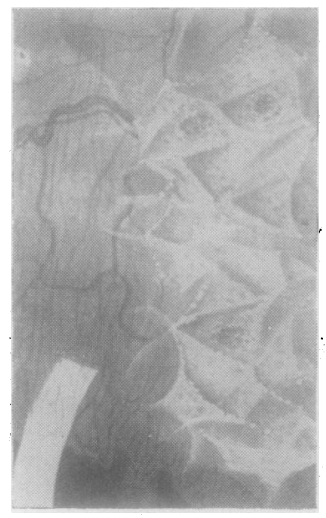

Fig. 1.-Early trachoma, rippled reflection.

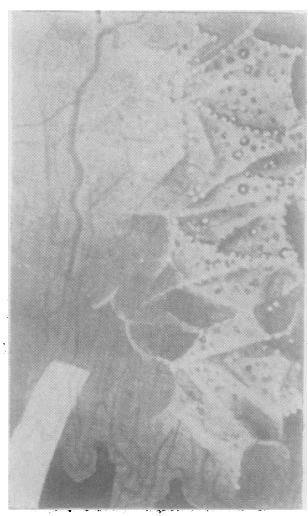

Fig. 2.-Late trachoma, goose-skin reflection.

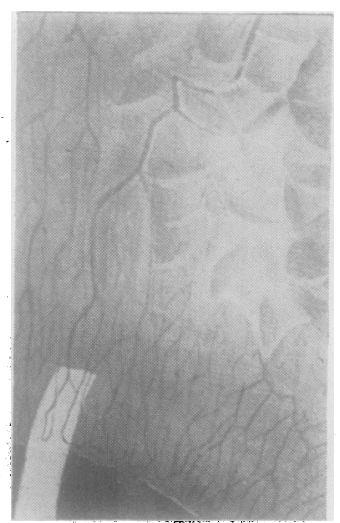

Fig. 3.-Normal conjunctiva bulbi.

* Received for publication January 10, 1951. 


\section{RESULTS}

(1) The reflection on the bulbar conjunctiva is of three types:

(a) An undulatory or rippled reflection accompanied by bubbly appearances, found in the initial stages of trachoma (Fig. 1).

(b) A reflection of goose-skin appearance, found at the height of trachoma (Fig. 2).

(c) A smooth, glossy reflection, always found on the normal conjunctiva (Fig. 3). This third type is also found in cases of epizootic conjunctivitis, which are free from trachomatous infection.

TABLE

PERCENTAGES OF TRACHOMATOUS REFLECTIONS

\begin{tabular}{|c|c|c|c|c|c|c|c|}
\hline \multirow{2}{*}{$\begin{array}{l}\text { Stage of } \\
\text { Trachoma }\end{array}$} & \multirow{2}{*}{$\begin{array}{c}\text { Number of } \\
\text { Eyes }\end{array}$} & \multicolumn{2}{|c|}{$\begin{array}{l}\text { Rippled } \\
\text { Reflection }\end{array}$} & \multicolumn{2}{|c|}{$\begin{array}{l}\text { Goose-skin } \\
\text { Reflection }\end{array}$} & \multicolumn{2}{|c|}{$\begin{array}{l}\text { Pannus } \\
\text { Positive }\end{array}$} \\
\hline & & No. & Per cent. & No. & Per cent. & No. & Per cent. \\
\hline I & 112 & 26 & $23 \cdot 2$ & 75 & $66 \cdot 9$ & 94 & 83.9 \\
\hline II & 82 & 3 & $3 \cdot 6$ & 78 & $95 \cdot 1$ & 70 & $85 \cdot 3$ \\
\hline III & 112 & 17 & $15 \cdot 1$ & 91 & $81 \cdot 2$ & 106 & $94 \cdot 6$ \\
\hline IV & 36 & 21 & $58 \cdot 3$ & 6 & $16 \cdot 6$ & 29 & $80 \cdot 5$ \\
\hline
\end{tabular}

(2) The Table shows the percentages of positive trachomatous reflections to be higher when inflammatory symptoms become more apparent.

(3) The trachomatous reflection is never found in the normal conjunctiva bulbi or in cases of epizoötic conjunctivitis, appears more distinctly in the upper quadrant of the conjunctiva bulbi than the lower, and is seen earlier and more frequently than pannus trachoma corneae, the actual percentage being higher than that for pannus in all phases except Stage IV.

(4) The same reflection is seen in inoculated trachoma as in that produced by natural infection.

When the conjunctiva bulbi was examined patho-histologically, hypertrophy, transformation, degeneration, proliferation, exfoliation, oedema, and disarrangement were found to a greater or less degree in the cells of the epithelial layer, and there was a certain degree of saturation in the sub-epithelial tissues, especially in the lymphocytes and plasma cells. These changes when slight give rise to the rippled appearances, and when more advanced to the goose-skin reflections.

After considerable clinical experience, the writers believe the slit-lamp examination should always be made so that the presence of pannus and the trachomatous reflection may be observed in the initial stages of the disease.

\section{REFERENCE}

MacCallan, A. F. (1936). "Trachoma”. Butterworth, London. 